\title{
THE LEGAL REGULATION OF RELIGIOUS SYMBOLS IN THE PUBLIC SPHERE IN POLAND
}

PAWEE SOBCZYK

\section{Introduction}

The presence of religious symbols in Poland's public space not only has religious and legal aspects, but also historical, cultural, and social dimensions. ${ }^{1}$ This is due to the state's historic close association with Christianity, the multicultural and multireligious nature of the First Polish Republic (until 1795), the time of partitions (17951918), the struggle for independence during the two world wars of 1914-1918 and 1939-1945, and the fight against communism (1945-1989). Over the state's highly complicated history, religious symbols (the Christian cross in particular) became symbols of identity, sovereignty, and tradition in addition to their basic, religious meaning. This can be indirectly confirmed by the wording of the Constitution of the Republic of Poland on April 2, 1997, framed during the political system changes initiated by the "Polish Round Table" talks in 1989. ${ }^{2}$ This was recalled by the Sejm of the Republic of Poland at a special resolution on December 3, 2009, stating, inter alia, that "the sign of the cross is not only a religious symbol [...], but in the public sphere, it is a reminder of the readiness to sacrifice for another human being, it carries the values that build respect for the dignity of every human being and their rights."

1 See e.g., Ożóg, 2010, pp. 55.

2 The importance of this context for the issues discussed in this paper was noted, for example, in Dudek, 2016, pp. 180-82.

Paweł Sobczyk (2021) The Legal Regulation of Religious Symbols in the Public Sphere in Poland. In: Paweł Sobczyk (ed.) Religious Symbols in the Public Sphere, pp. 103-140. Budapest-Miskolc, Ferenc Mádl Institute of Comparative Law-Central European Academic Publishing. 
Following up on that statement, it further stressed that "in difficult times, during the partitions and occupation [...], the cross became a symbol not only of Christianity and its values, but also of longing for the Homeland." 3 A similar statement was adopted by the Senate of the Republic of Poland in the resolution of February 4, 2010, concluding that "any attempt to prohibit the placement of the cross in schools, hospitals, offices, and public spaces in Poland must be considered contrary to our tradition."

The scope and methodology of the research described in this paper are in line with those of the international research project Freedom of Conscience and Religion in Europe pursued within the framework of the Central European Professors' Network coordinated by the Ferenc Mádl Institute of Comparative Law in Budapest (Hungary).

At the conceptual stage of research work on a multi-authored monograph titled Religious symbols in the public sphere in the legal orders of Central and Eastern European countries, a team of experts from Croatia, Czechia, Slovakia, Serbia, Hungary, and Poland proposed the following structure:

1. Introduction: scope of research, methodology, basic concepts.

2. The historical, social, cultural, and political context of the presence of religious symbols in public spaces: political transformations of state after 1989 and their impact on the protection of freedom of conscience and religion.

3. Axiological and constitutional foundations: values and principles related to the presence of religious symbols in public spaces.

4. Model of relations between the state and the Church: general principles, practice of cooperation between the state and religious associations.

5. Constitutional guarantees of freedom of conscience and religion: basis, subject, object, limits, and means of protection.

6. Guarantees according to other sources of universally binding law: the subjective and objective scope of the possibility of manifesting religious beliefs through religious symbols.

7. Limits of religious expression through religious symbols: public offices, schools and universities, hospitals, workplaces, business activities, the Internet, and social networks.

8. The system of legal protection: the practice of the judiciary, case studies.

9. Conclusions de lege ferenda.

At the outset, a linguistic remark should be made. The word "symbol" in Polish has several meanings. According to Dictionary of the Polish Language, symbol

3 Resolution of the Sejm of the Republic of Poland of 3 December 2009 (Monitor Polski of 2009, No. 78, item 962).

4 Resolution of the Senate of the Republic of Poland of 4 February 2010 (Monitor Polski of 2010, No. 7, item 57). Both resolutions of the chambers of the Polish Parliament were issued after the judgement of the European Court of Human Rights of 3 November 2009 in the case of Lautsi v Italy. 
denotes: "1. a concept, object, sign, etc., having one literal meaning and more hidden meanings; 2. a person or an animal personifying something; 3. a conventional sign to denote something, for example, units of measurement, chemical elements, etc.; 4 . in literature: a motif or set of motifs in a literary work which is a sign of a deeper, hidden content, intended to suggest its existence." 5

A "religious symbol," in turn, belongs to the sphere of religious worship (religion) and is used or clearly associated with a religious system. Often, religious symbols are given additional mystical or magical meanings. The genesis of religious symbols varies; religious symbols do not have a "genetically" religious origin. ${ }^{6}$

\section{Historical, social, cultural, and political context of the presence of religious symbols in public spaces}

Articles concerning religious matters had a special place in the Polish constitutions of $1791,{ }^{7} 1921,{ }^{8} 1935,{ }^{9}$ and even $1952,{ }^{10}$ defining the legal standing of an individual due to the professed religion and the legal standing of religious associations, especially the Catholic Church. ${ }^{11}$ An analysis of religious matters in these four constitutions indicates that the provisions concerning religion were outcomes of debates or even fierce constitutional disputes (often taking longer to resolve than the work on solutions for the system of government), ultimately ending with a political and legal agreement in accordance with the principle of consensus facit legem (except 1952). The complex national and state tradition, in which the religious factor in the functioning of the state and its bodies and institutions has played an essential role, has

5 Słownik Języka Polskiego [Online], https://sjp.pl/symbol.

6 Cf. Szymanek, 2012, 33ff.

7 Government Act of 3 May 1791. The first article of that Constitution was titled "The Prevailing Religion" and read as follows: "The prevailing national religion is and shall be the sacred Roman Catholic faith with all its laws. Passage from the prevailing religion to any other confession shall be forbidden under penalties of apostasy. Inasmuch as that same holy faith bids us to love our neighbours, we owe to all persons, of whatever persuasion, peace in their faith and the protection of the government, and therefore we guarantee freedom to all rites and religions in the Polish lands, in accordance with the laws of the land."

8 The religious provisions of the Constitution of 17 March 1921 were framed in two blocks of articles. The first comprised provisions on the freedom of conscience and religion (Articles 54, 111, 112, and 120), while the other regulated institutional relations (Articles 113-116). Constitution of the Republic of Poland of 17 March 1921 (Journal of Laws No. 44, item. 267).

9 The Constitution of 23 April 1935 incorporated religious provisions of the March Constitution, with one exception-the Preamble did not include invocatio Dei.

10 Constitution of the Polish People's Republic of 22 July 1952 (consolidated text: Journal of Laws of 1976, No. 7, item 36).

11 For a detailed and comparative analysis of the relationship between the state and religious organizations in Polish Constitutions, see Sobczyk, 2019, pp. 259-296. 
had a significant impact on the framing of religion-related provisions in the Polish Basic Laws. In addition to the essential guarantees of the freedom of conscience and religion for individuals, the provisions governing state-Church relations were of key importance, confirming the primus inter pares status of the Catholic Church vis-à-vis other religious associations due to the state's centuries-long association with it. ${ }^{12}$

The direct constitutional legacy that the framers of the current Basic Law faced after 1989 were the provisions of the Constitution of the Polish People's Republic of July 22, 1952. The religious article of the 1952 Constitution also remained in force after the adoption of the Constitutional Act of October 17, 1992, on mutual relations between the legislative and executive powers and on local government, or the "Small Constitution," 13 although its meaning and interpretation were completely different due to the process of systemic transformation that started in 1989 and the adoption of the "religious laws," among which the Act on guarantees of freedom of conscience and religion and the Act on the relations between the state and the Catholic Church in the People's Republic of Poland were of fundamental importance. ${ }^{14}$

The religious article in force at the time of the commencement of work on the new Basic Law read as follows: "1. The Republic of Poland guarantees freedom of conscience and religion to its citizens. The Church and other religious associations are free to perform their religious functions. Citizens may not be compelled to participate in religious activities or rites, nor may anyone be forced to participate in religious activities or rites. 2 . The church is separate from the state. The principles of the relationship between the State and the Church as well as the legal and property standing of religious associations shall be determined by statutes." ${ }^{\prime 5}$ With some exceptions, the multiple amendments to the constitutional provisions did not affect the religious article. These changes consisted of the 1976 repeal of para. 3 in the following wording: "The abuse of the freedom of conscience and religion for purposes detrimental to the interests of the Polish People's Republic shall be punishable."

The centuries-old history of the state's linkage with the Catholic Church and its supra-religious role in the history of the nation meant that the Church could not be missing in an important period of political and socio-economic changes, which began with the round table talks in 1989. Moreover, various axiological, historical, legal, and social factors contributed to the conviction that the new Basic Law should

12 For interesting considerations on the presence and role of religious symbols in religious and secular states, see Szymanek, 2012, p. 33.

13 Constitutional Act of 17 October 1992 mutual relations between the legislative and executive powers and on local government (Journal of Laws No. 84, item 426, as amended).

14 Act of 17 May 1989 on guarantees of freedom of conscience and religion (consolidated text: Journal of Laws of 2000, No. 26, item 319, as amended), and the Act of 17 May 1989 on the relations between the State and the Catholic Church in the Republic of Poland (Journal of Laws No. 29, item 154, as amended). The third of the 'May Acts' was the non-binding Act of 17 May 1989 on the social insurance of clergy (Journal of Laws No. 29, item 156, as amended).

15 The issues concerning freedom of conscience and religion as well as the principles of state-Church relations were covered in Article 70 of the 1952 Constitution, and then-following the amendment and renumbering-in Article 82. 
include completely new provisions concerning the freedom of conscience and religion and the status of religious associations in the state. In the case of individual guarantees, the model that the Constitution framers were bound to replicate was the 1993 Convention for the Protection of Human Rights and Fundamental Freedoms and the accession of the Republic of Poland to the Council of Europe.${ }^{16}$ However, in the case of the relations between the state and the Church, the available options were extremely broad, as they were determined not by historical experience or international standards, but by current politics. The Polish Constitution framers faced several problems in defining the institutional relations between the state and the Church. The first was due to the need to determine the wording of the provisions to be included in the constitution. The other, of a substantive nature, concerned the choice and definition of the state model from the perspective of its attitude to religion, philosophical views, and institutional religious subjects. ${ }^{17}$

The drafters of the new Constitution, including the provisions on religious matters and indirectly on the presence of religious symbols in public spaces, faced the challenge of determining the state bodies that would be legitimized to proceed with framing the new Constitution and the procedure for constitutional work. The 1952 Constitution, apart from the amendments to its specific provisions, did not resolve any matters in the event that the need to adopt a new constitution should arise. Józef Krukowski rightly highlighted that the developments in religious policies in the countries of Central and Eastern Europe after 1989 were influenced by two factors, namely the respect for religion as a fixed component of national culture, and the assumptions of liberalism, including the postulate for building a secular state, neutral in matters of religious beliefs, accompanied with the postulate for respect for the freedom of conscience and religion. ${ }^{18}$ It must be emphasized that in the Polish reality, placing crosses in public places was not only an expression of attachment to the Catholic religion and Polish traditions, but also a reaction to the concept of an irreligious state that was actively promoted by the authorities of the Polish People's Republic. ${ }^{19}$

The work on the new constitution formally commenced on December 7, 1989 when the Sejm of the 10th term and the Senate of the first term appointed their constitutional committees. ${ }^{20}$ The work was completed only after nearly eight years of

16 Convention for the Protection of Human Rights and Fundamental Freedoms, 4 November 1950, as amended (Journal of Laws of 1993, No. 61, item 284).

17 Cf. Krukowski, 1993, pp. 319-330.

18 Cf. Krukowski, 2002, p. 9.

19 Justification for the judgement of the Court of Appeal in Szczecin of 25 November 2010, case ref. I ACa 363/10, 2012, Przegląd Prawa Wyznaniowego, no. 4 (2012): 195-218 (cited from p. 201).

20 The path of subsequent amendments to the Constitution of the People's Republic of Poland in the years 1989-1993 was described, among others, by Maria Kruk. She pointed out that the Small Constitution, in the "inter-Constitution" period, "could well be an attempt to provide teaching on new principles and rules and on the need to abide by these in the interests of the culture of exercising power, efficiency, stability and effectiveness of government" (Kruk, 1993, p. 17). 
extremely politically and legally turbulent debates, with the adoption of the Constitution of the Republic of Poland on April 2, 1997. ${ }^{21}$

Regardless of the legal context, as a consequence of the processes described above, crosses once again became a fairly common element in the Polish public space, although their presence was not required by any legislation.

\section{Axiological and constitutional foundations}

The enactment of the Constitution of the Republic of Poland on April 2, 1997, represented a certain political and legal consensus, especially since the majority in the National Assembly, which framed and adopted the text of the Constitution, vested in the post-communists, and the influence of the circles linked to the Solidarity movement (i.e., the anti-communist opposition of the 1980s) on final wording was limited. This was confirmed by the results of the constitutional referendum of May 25, 1997, which preceded the signing of the Polish Constitution by the President and its entry into force on October 17, 1997. Citizens voting in favor of the Constitution numbered 6,396,641 (53.45\%) and 5,570,493 were against it (46.55\%), with a turnout of merely $42.86 \% .^{22}$

The 1997 Constitution does not directly refer to the presence of religious symbols in public spaces. However, this does not mean that its text does not contain any significant provisions related to the issues discussed. On the contrary, both the religious provisions (Articles 25 and 53) and other provisions (e.g., the Preamble) refer to the presence of religious symbols in public spaces.

Articles 25 and 53, which are of key importance in terms of religious matters, are discussed below in this paper; at this point, one should note the linking of the presence of religious symbols in public space to a number of other constitutional provisions ${ }^{23}$ that form an intermediate axiological and systemic context.

First, one should consider the Preamble and the references it contains to religious matters. The excerpt of the Preamble, "We, the Polish Nation-all citizens of the Republic, both those who believe in God as the source of truth, justice, good and beauty, as well as those not sharing such faith but respecting those universal values as arising from other sources," indicates respect for pluralism regarding philosophical

21 Journal of Laws, No. 78, item 483, as amended.

22 The voting results and revised voting results can be found in the Journal of Laws-the original results: Journal of Laws of 1997, No. 54, item 353; for the revised results and Notice of the National Electoral Commission of 8 July 1997 on the revised voting results and the outcome of the constitutional referendum held on 25 May 1997, see Journal of Laws No. 75, item 476.

23 For the systematics of the constitution and the positioning of the religious provisions in the constitutions of modern states and the 1997 Constitution of the Republic of Poland, see, among others, Szymanek, 2000, 22-39. 
views in society and equal treatment of the "sources of values." Moreover, it confirms that the state treats all religious and philosophical options in the same manner, "that is, that their followers have equal rights to manifest their postulates regarding respect for their recognized values towards state authorities, including postulates resulting from convictions as to the existence of Christian values." ${ }^{24}$ Further, another excerpt from the Preamble states: "Beholden to our ancestors for their labors, their struggle for independence achieved at great sacrifice, for our culture rooted in the Christian heritage of the nation and in universal human values," which refers to the tradition and history of the Polish state and emphasizes the importance of the Nation's Christian heritage for culture. One may challenge that the Christian heritage of the nation should be important only for culture, as it is for other areas of life. The last of the three excerpts on philosophical and religious matters reads as follows: "Recognizing our responsibility before God or our own consciences, we hereby establish this Constitution of the Republic of Poland." This excerpt, both during and after the completion of the work on the Preamble, has raised many controversies. Catholic Church representatives proposed that the word "or" should be replaced with the conjunction "and." They rightly pointed out that responsibility before God does not make void or supersede responsibility before one's conscience. On the other hand, account had to be taken of the opinions of secular circles, for which such a change could lead to the invalidation of the autonomy of conscience in relation to religious faith. ${ }^{25}$ Therefore, one should agree with Krukowski that "[s] uch a provision indicates that the Constitution of the Republic of Poland assumes an ethical relativism characteristic of liberal democracy." ${ }^{26}$ The dispute over this provision really concerns the meaning of the conjunction "or." This conjunction, next to, inter alia, the conjunctions "and," "if ... then," "always and only if," is a binary truth-functional connective. The problem is that the conjunction "or," as used in the above-discussed provision of the Preamble by the Constitution framers, has three different meanings that may complicate the construction of this part of the Preamble. ${ }^{27}$

Chapter I of the Polish Constitution, among the principles defining the relations between the state and the Church, in Article 25(2), lays down the principles of the impartiality of public authorities in matters of religious and philosophical beliefs, as well as the freedom to express religious and philosophical beliefs in public life. These do not directly refer to the relationship between Church and state. ${ }^{28}$ However, the relationship between constitutional impartiality and equality cannot be denied. As the Constitutional Court noted, "The principle of impartiality precludes the enactment of any regulations that would significantly differentiate the legal standing

24 Krukowski, 1999, p. 66.

25 Cf. Gowin, 1999, p. 246.

26 Krukowski, 1999, p. 66.

27 For more about the conjunction “or," see, among others, Stanosz, 2000, p. 20; Ziembiński, 1992, pp. 76-77.

28 Cf., for example, Małajny, 2002, p. 293, and Szymanek, 2004, pp. 32-33. 
of religious communities in terms of the material foundations of their activities. In a situation in which the contested provision on the material conditions of the activity of religious communities does not violate the principle of their equality, there are no grounds to conclude that it goes beyond the scope of the regulatory freedom delimited by the principle of impartiality under consideration." ${ }^{29}$

Representatives of the Polish doctrine of constitutional and religious law, during the work on this constitutional provision and after its enactment, held fierce discussions over the meaning of "impartiality," especially in the context of this concept notoriously conceived in its negative meaning of "neutrality." 30 It was noted, among others, that "neutrality" and "impartiality" are synonyms, and the essence of the constitutional compromise in this matter lies in the clarification of the principle of "neutrality" by "adding a clause to guarantee the respect by the state authorities of the freedom to express religious and philosophical beliefs in public life." This clarification is dictated by the need to prevent any risks that could arise from a radical understanding of neutrality. ${ }^{31}$ The need for clarification arose during the framing of the 1997 Constitution due to the ambiguity of neutrality and the use of the concept of ideological neutrality of the state in the times of the People's Republic of Poland to fight religion and its manifestations both in the individual (individual's religious freedom) and community aspects (religious freedom of churches and other religious associations). ${ }^{32}$

To interpret the principle of impartiality of public authorities in matters of religious and philosophical beliefs, it is important to distinguish between the neutrality of authorities towards religion in a closed and open sense. Neutrality refers to the removal of all manifestations of religious beliefs from public life, while the contemporary doctrine speaks of impartiality (neutrality) of public authorities in an open sense. ${ }^{33}$ The elimination of manifestations of religious and philosophical beliefs may consist, inter alia, of the prohibition of the participation of those holding public office in religious ceremonies on the occasion of state celebrations or the prohibition of placing religious symbols in state premises, even if those employed wish to do so. The formula of neutrality in the open sense applies to public authorities and requires them to treat all people equally, regardless of their religious or philosophical beliefs: neutrality, as Leszek Garlicki states, "must not undermine the cultural tradition

29 Judgement of the Constitutional Court, case ref. K 3/09 (OTK ZU no. 5/A/2011).

30 Cf. Dudek, 2016, p. $184 \mathrm{ff}$.

31 Krukowski, 2000a, pp. 106-107.

32 For more on this see, for example, Borecki, 2008.

33 Cf. Krukowski, 2006, p. 62. Jarosław Szymanek was negative about the distinction between open and closed neutrality in Szymanek, 2004, p. 43. In his opinion, "neutrality, to be neutrality at all, and therefore an objective attitude towards other people's matters and other people's disputes, can actually be only one, i.e., indifferent." It seems that this author, bringing the charge of logical nonsense against the authors who make such classifications of neutrality, is making a substantial error himself. The point is not, on the constitutional level, whether neutrality has an open or closed form, but about the way in which it is applied by bodies of public administration, and that is something completely different. 
of individual societies, which should and is reflected in normative acts." ${ }^{34}$ At the same time, this formula implies the obligation to refrain from accepting one religion, opinion, or philosophy as the only true one..$^{35}$

Article 25(2) in fine provides for an obligation on public authorities to ensure conditions for the free expression of religious and philosophical beliefs by everyone in public life. ${ }^{36}$ "Public life" should be understood as the opportunity to present views at public gatherings or in the press, for example. However, the right to present one's views is not absolute and may, therefore, be subject to generally accepted limitations. Article 31(3) of the Constitution is of fundamental importance regarding restrictions on the freedom of expression of religious and philosophical beliefs: "any limitation upon the exercise of constitutional freedoms and rights may be imposed only by statute, and only when necessary in a democratic state for the protection of its security or public order, or to protect the natural environment, health or public morals, or the freedoms and rights of other persons. Such limitations shall not violate the essence of freedoms and rights." This article contains the classic dyad of limitations due to bonum commune (state security, public order, environmental protection, public health, and morality) and iura aliorum (freedoms and rights of others).

For a proper understanding of religious matters regulated under the Constitution, including the presence of religious symbols in public spaces, other provisions of Chapter I of the Constitution are also of fundamental importance: Article 1, laying down the concept of the state as the common good ("The Republic of Poland shall be the common good of all its citizens"); Article 2, in which the Constitution framers state that "The Republic of Poland shall be a democratic state ruled by law and implementing the principles of social justice"; Article 5, with its provisions categorized as program norms that establish the objectives and stages of the state's activities and the means for their achievement ("The Republic of Poland shall safeguard the independence and integrity of its territory and ensure the freedoms and rights of persons and citizens, the security of the citizens, safeguard the national heritage [emphasis added] and shall ensure the protection of the natural environment pursuant to the principles of sustainable development"); and Article 6(1), reading as follows: "The Republic of Poland shall provide conditions for dissemination and the people's equal access to the products of culture which are the source of the Nation's identity, continuity, and development"). ${ }^{37}$

P. Stanisz notices that, regardless of the above-mentioned constitutional guarantees concerning the presence of religious symbols in public spaces-the natural rights of national and ethnic groups (and, consequently, also of their individual members), to cultivate traditions and behaviors that they have developed as such, 
are also of great importance for the issues under consideration. ${ }^{38}$ In this context, one cannot omit Article 35(1) of the Polish Constitution, which provides that "the Republic of Poland shall ensure Polish citizens belonging to national or ethnic minorities the freedom to maintain and develop their own language, to maintain customs and traditions, and to develop their own culture" (emphasis added). This provision should be construed in the context of Articles 5 and 6 of the Basic Law.

Regarding Chapter II of the Polish Constitution, titled "The freedoms, rights and obligations of persons and citizens," next to the above-mentioned Article 53, which defines the freedom of conscience and religion, Article 48 is key, and especially its para. 1 concerning parents' right to raise their children according to their beliefs (the second sentence of that paragraph states that "such upbringing shall respect the degree of maturity of a child as well as their freedom of conscience and belief and also their convictions"). Moreover, the triad of articles defining the values of dignity, freedom, and equality as the source, foundation, and interpretation rules for the entire catalog of freedoms, rights, and obligations of persons and citizens should be noted. Further, one may count among the provisions of Chapter II of the Polish Constitution concerning religious matters, a specific list of means for the defense of freedoms and rights contained in Articles 77-81, as discussed in more detail below. ${ }^{39}$

\section{Model of relations between the state and the Church}

The model of relations between the state and religious associations applicable in Poland comprises the principles stipulated in Article 25 of the Constitution: equality of rights of churches and other religious associations, respect for the autonomy and mutual independence of the state and of churches and other religious associations, cooperation between the state and churches and other religious associations for the individual and the common good, and legal forms for structuring relations between the state and religious associations. ${ }^{40}$

The constitutional regulation of the relations between the state and institutional religious subjects is essentially specific in that a single article of the Polish Constitution contains a catalog of principles that correspond directly to the wording of the article itself. The religious article is positioned in Chapter I of the

38 Stanisz, 2016, pp. 171-172.

39 The means for the defence of human and citizen freedoms and rights guaranteed in the Polish Constitution of 2 April 1997 include, first of all: the right to a fair trial, an individual constitutional complaint and an application to the Commissioner for Citizens' Rights. Cf. Garlicki, 2012, pp. 116-117.

40 For more on this, see Sobczyk, 2013. 
Basic Law, among the supreme constitutional principles. ${ }^{41}$ Undoubtedly, this was due to historical factors and awareness of the importance of religious matters in Poland. ${ }^{42}$ As Garlicki noted, "Poland's specific historical experience, especially the role of the Catholic Church, requires that churches and religious organizations be included in political considerations of civil society. This is what the Constitution envisages by introducing into the principles of the political system of the Republic of Poland, in addition to guarantees of conscience and religion to individuals (Article 53), a general definition of the role of churches and religious organizations." ${ }^{\prime 3}$

In a brief description of the principles that compose the Polish model of relations between the state and religious associations, one should follow their systematics as adopted by the Constitution framers. Article 25(1) sets out the principle of equal rights of churches and other religious associations, which is a complement and a determination of the principle included in Article 32 of the Polish Constitution (equality before the law), as emphasized several times by the Constitutional Court in its jurisprudence. ${ }^{44}$ Hence, the principle opening the constitutional religious article must be construed not only on the basis of the literal rule of interpretation, which takes into account the meaning of such terms as "equal rights" or "Churches and other religious associations," but also in the context of guarantees of respect for equality in the law and before the law, along with inherent human dignity.

The framers of the Polish Constitution did not define the principle of equal rights, but merely stated in general terms that "Churches and other religious organizations shall have equal rights." A definition of this principle, based on the established jurisprudence regarding the principle of equal rights, was only given by the Constitutional Court, according to which "the principle of equality of churches and religious organizations means that all churches and religious organizations with a shared essential feature should be treated equally. At the same time, this principle assumes a different treatment of churches and religious organizations that do not have a common feature that is essential from the point of

41 In the judgement on the constitutionality of the Property Committee, the Constitutional Court stated, inter alia, that "the regulations on the institutional position of churches and religious associations, as contained in Article 25 of the Constitution, were given by the Constitution framers the form of a systemic principle." Cf. the Constitutional Court's judgement of 8 June 2011 (case ref. K 3/09), item 39. Further, Michał Pietrzak concluded that the opinion that this regulation was important for the state model, which prevailed among deputies and senators, was decisive in giving religious matters such a high rank and the establishment of their positioning among the political system principles. Cf. Pietrzak, 1997, p. 176.

42 Cf. Winczorek, 1995b, p. 71.

43 Garlicki, 2012, p. 69.

44 E.g., in the judgement concerning the Act of 26 June 1997 amending the Act on guarantees of freedom of conscience and religion and amending certain other acts. Judgement of the Constitutional Court of 5 May 1998, case ref. K 35/97 (OTK ZU no. 3/1998), item 32. 
view of a regulation." ${ }^{45}$ The Constitutional Court, by supporting the construction of the principle of equality of rights on the concept of equality before the law and equality in the law, as inferred from the principle of equality established in Article 32 of the Basic Law, came to the conclusion that the essence of the principle of equal rights of churches and religious organizations lies in the assumption that all churches and religious organizations, which share essential features, should be treated equally. This principle also assumes a different treatment of churches and other religious organizations that do not have common features, which is essential from the perspective of regulations. ${ }^{46}$ In other words, the principle of equal rights of churches and religious organizations does not presume that all religious organizations should be treated in the same way. It is a merely guarantee that public authorities will create a legal framework that will enable the achievement of equal rights, depending on the features and characteristics of individual churches and religious associations. ${ }^{47}$ This means that equal rights, such as equality, are not equivalent to egalitarianism. ${ }^{48}$

The differences between religious subjects must have been recognized by the Constitution framers, since in Articles 25(4) and (5) they provide different definitions of the legal status of individual institutional religious subjects. ${ }^{49}$ Moreover, it follows from Article 53(4) that teaching religion in public schools is possible only for churches and other "legally recognized" religious organizations. ${ }^{50}$

Due to the inclusion of the framers of the current Polish Constitution of the principle of equal rights of churches and other religious associations among the basic principles of state-Church relations, there is no privileged (supreme) religious denomination in Poland, nor any legally privileged Church or other religious organization.

45 Judgement of the Constitutional Court, case ref. K 13/02; cf. Paweł Borecki, who points to three different constructions of the principle of equal rights of religions in the Polish constitutional and religious law. In his opinion, the Constitutional Court in the cited judgement referred to the position supported by Józef Krukowski, Artur Mezglewski, Henryk Misztal, Piotr Stanisz, as well as Witold Adamczewski and Bogusław Trzeciak. According to Borecki, its opposite is the stance of Michał Pietrzak and Piotr Winczorek, who believe that it follows from the principle of equal rights that neither Churches nor religious organizations can be granted a legally privileged position in Poland. In his opinion, the optimum solution is the one proposed by Zbigniew Łyko, who recognizes equality of rights as the right to equal opportunities, i.e., the same legal opportunities for religious associations; see Borecki, 2007, pp. 134-38.

46 Cf. the Constitutional Court's judgements: K 13/02 and K 3/09.

47 Judgement of the Constitutional Court, case ref. K 3/09. Andrzej Czohara wrote that the principle of equal rights of religious associations requires the state to treat them equally and to provide them with equal rights; see Czohara, 1994, p. 25.

48 Cf. Dudek, 2004, p. 201.

49 This was pointed out by the Constitutional Court, which noted that the equality of rights of churches and other religious organizations is not inconsistent with the differentiation of the status of individual religions, stressing that the principle of institutional equality of rights cannot be understood as a principle creating the expectation of factual equality; see the $\mathrm{K} 3 / 09$ judgement.

50 Ibid. 
They all enjoy the same rights and have the same obligations. ${ }^{51}$ As a further consequence, this principle precludes the emergence of a confessional state that grants one of the churches or other religious organizations the position of the state Church.

Article 25(3) of the Polish Constitution established the principles of autonomy and independence. It is quite commonly accepted that in religious articles, it plays the role of a "principle of principles" in defining the relations between the state and institutional religious subjects. ${ }^{52}$ It follows from the meaning of the term "autonomy" in the Polish language and the wording of Article 25(3) that, on the basis of the religious article, one can speak of the autonomy of churches and other religious organizations in relation to the state, as a certain sphere of their activity, with which the state does not interfere. ${ }^{53}$

However, delimitation of the sphere of autonomy remains an open question, as it was left undefined by the framers of the constitution, leaving this issue to the ordinary legislator. ${ }^{54}$ The wording finally adopted in the Constitution, which establishes "the principle of respect for their autonomy and the mutual independence of each in its own sphere" as the basis of relations between the state and churches and other religious organizations indicates that the state does not grant autonomy and independence to institutional religious subjects. The state only confirms that it exists and undertakes respect to it.

The constitutional principle of autonomy and independence is, in the subjective aspect, a confirmation of the separated nature of the two institutions of public life, the state and churches, and other religious associations. ${ }^{55}$ The constitutional drafters,

51 Cf. Majchrowski and Winczorek, 1998, p. 48. Jarosław Szymanek, in contrast, writes that the principle of equality of rights established in Article 25(1) of the Polish Constitution is an obligation on the part of the state to treat Churches and other religious associations equally before laws. At the same time, equality of rights understood in this way cannot create an expectation towards factual identity of rights, as to extrapolate their absolute equality would be unwarranted and exaggerated. Cf. Szymanek, 2006, pp. 97-98.

52 This conclusion is warranted both by the genesis of the religious article and the role of autonomy and independence in shaping the relation between the state and institutional religious subjects.

53 This matter was construed in a similar manner by the representative of the President of the Republic of Poland in the Constitutional Committee Władysław Kulesza, who stated, among other things: 'Therefore, it is not about mutual autonomy; the state vis-à-vis the Church, and the Church vis-à-vis the state, but one-way autonomy between the state and the Church;' see Kulesza, 1995, p. 69. On the other hand, Włodzimierz Cimoszewicz considered the wording concerning the autonomy and independence of Churches and the state to be a logical error, in that the state cannot be defined with the use of a feature of autonomy in relation to Churches; see Cimoszewicz, 1995, p. 79; Działocha, 1995, p. 8. As the principle established during the Second Vatican Council demonstrates, the Catholic Church perceives autonomy and independence in a different way. The Pastoral Constitution on the Church in the Modern World Gaudium et spes provides that 'The Church and the political community in their own fields are autonomous and independent from each other;' see Sobczyk, 2005, pp. 154ff.

54 Wiktor Osiatyński, one of the experts of the Constitutional Committee, proposed to limit the autonomy of Churches and other religious organizations to religious and organizational functions, while recognizing that activities of a different nature, e.g., charitable work, would find their justification in the principle of cooperation between the state and Churches and others religious organizations; cf. Osiatyński, 1995, p. 87.

55 Winczorek, 2000, p. 39. 
as the wording of the provision demonstrates, do not grant institutional religious subjects autonomy, but only confirm their special status in the state. ${ }^{66}$ Therefore, the position presented in the doctrine of constitutional law, from which it follows that the subjects of religious relations have their objective value seem fully legitimate. ${ }^{57}$

The fact that the principle of respect for the autonomy and independence of the state and the Church implies that power vesting in each of these subjects to legislate their own law is not tantamount to consent to the infringement of the law established by the other subject. Churches and other religious associations are required to respect the state legal order and vice versa, as they are subjects operating in the state and in accordance with Article 83 of the Constitution, they are under a constitutional obligation to observe the law: "Everyone shall observe the law of the Republic of Poland."

The special character and, at the same time, the legal position of institutional religious subjects finds its confirmation in "mutual independence of each in its own sphere." It follows from this wording that the independence provided for the state and the Church is not absolute, that is, complete. Its boundaries are delimited by the constitutional wording "in its own sphere"; hence, the distinction of the objective aspect of the principle. It seems that in this way, the Polish Constitution framers indirectly referred to the classical division of matters of interest to the state (res temprorales) and the Church (res spirituales). These spheres were specified in detail at the constitutional level, as any such determination is the subject matter of an international agreement and acts governing the status of religious associations, pursuant to Article 25(4) and (5) of the Polish Constitution.

The relationship between the state and churches and other religious organizations are structured around the principle of cooperation for the good of the individual and the common good. This is a confirmation of their autonomy and mutual independence: each in its own sphere, and there is an assignment of a positive meaning to the separation of these subjects. The principle of cooperation, rooted in European legal culture since the times of Emperor Constantine the Great (4th century CE), serving in the religious article primarily to define the relations between the state and the Church, may be considered a necessary principle because of the affiliation of the same people to the state and the Church. In the author's opinion, it is also a form of involvement of churches and other religious associations under the Constitution in the pursuit of state objectives, in accordance with the principle of subsidiarity and the common good, which indirectly manifests the position and role of institutional religious subjects in a democratic state ruled by law. ${ }^{58}$

However, the Polish Constitution does not specify what is meant by the terms that set out the objectives of cooperation. The "individual good" seems to be a clearer

56 The special status of Churches and other religious associations in the state is confirmed by their autonomy and independence and vice versa.

57 This e.g., in Krukowski, 2006, p. 74.

58 Cf. Mojak, 2007, p. 96. 
term which, in the context of the Preamble to the Constitution, can be identified with dignity of a person, as but also with the guarantees of respect for rights and freedoms of persons and citizens. ${ }^{59}$ However, the problem with interpretation may be that the individual good as a constitutional category appears only in the context of cooperation, as referred to in Article 25(3). The common good as an objective of cooperation between the state and churches and other religious organizations should be interpreted in the context of the wording of the Constitution, which contains a direct reference to this idea and value in the Preamble, ${ }^{60}$ Articles 1 and $82,{ }^{61}$ as well as that which creates this concept indirectly, for example, as a delimitation category relating to the freedom of persons and citizens (Article 31(3)). ${ }^{62}$

Cooperation is a general obligation to pursue activities aimed at achieving the individual and common good. At the same time, the drafters did not specify any forms of cooperation or areas of activity that would be the object of the subjects' joint activities mentioned in the religious article. They only provided for a duty for permanent dialog guided by respect for the autonomy and mutual independence of the subjects specified in Article 25 of the Polish Constitution.

The drafters rightly did not specify in detail the areas of cooperation between the state and churches and other religious associations, but only pointed to their objectives. This, in turn, is a task for the ordinary legislator, and in the case of the Catholic Church, a task for the parties to an international agreement signed between the Republic of Poland and the Holy See. Hence, a number of legal acts set out the obligation of the state to cooperate with churches and other religious associations.

In Article 25(4), they resolved that "[t]he relations between the Republic of Poland and the Roman Catholic Church shall be determined by the international treaty concluded with the Holy See and by statute." Further, Article 25(5) contains the following provisions: "The relations between the Republic of Poland and other churches and religious organizations shall be determined by statutes adopted pursuant to agreements concluded between their appropriate representatives and the Council of Ministers." The diversification of the definition of the relations between the Republic of Poland and the Catholic Church as well as other churches and

59 Among other things, the Preamble to the Constitution states: "We call upon all those who will apply this Constitution for the good of the Third Republic to do so paying respect to the inherent dignity of the person, his or her right to freedom, the obligation of solidarity with others, and respect for these principles as the unshakeable foundation of the Republic of Poland."

60 In the preamble to the Constitution, the common good is equated with Poland: "equal in rights and obligations towards the common good-Poland."

61 Article 1 of the Polish Constitution provides that "[t]he Republic of Poland shall be the common good of all its citizens,' while in Article 82, the one opening the constitutional catalogue of obligations, the Constitution framers envisaged that "Loyalty to the Republic of Poland, as well as concern for the common good, shall be the duty of every Polish citizen."

62 In the delimitation category of the common good concerning limitations in the use of constitutional freedoms and rights, the Constitution framers included in Article 31(3): state security, public order, environmental protection, public health and morality. It should be noted that another delimitation category refers to the freedoms and rights of others. 
religious associations raises a question about the justification of the concept adopted by the Constitution framers. Nevertheless, the Constitution framers, taking due account of historical and legal reasons, including the specific character of the Catholic Church and other institutional religious subjects without legal personality under public international law, resolved to diversify the aforementioned forms under which the relations between the state and religious subjects are regulated. ${ }^{63}$

In Article 25(5), the Constitution framers set out provisions concerning the need for an agreement to be entered into between the Council of Ministers and the relevant representatives of a religious organization before a religious act would be adopted. Unfortunately, despite the fact that the Polish Constitution has been in force for almost 25 years, relevant procedures for the implementation of this constitutional norm have not been developed. The practice in this area should be considered insufficient and marginalizing the constitutional position and role of institutional religious subjects. ${ }^{64}$

\section{Constitutional guarantees of freedom of conscience and religion}

Article 53 of the Polish Basic Law is modeled on Article 9 of the European Convention for the Protection of Human Rights and Fundamental Freedoms. This Article is one of the most extensive constitutional provisions and contains several

63 This understanding of equality of rights and diversification in the forms for regulating these relations was raised during the first session of the subcommittee for the foundations of the political and socio-economic system, which discussed the issue of equal rights (2 December 1994) by the expert of the Constitutional Committee of the National Assembly Piotr Winczorek (Winczorek, 1995a, p. 153). The equality of rights was also mentioned as one of the principles determining the relations between the State and the Church by another expert to the Committee, Leszek Wiśniewski (Wiśniewski, 1995, p. 154). As was mentioned in the first chapter of the monograph, representatives of the Catholic Church repeatedly pointed out that the Church supported the principle of equal rights of Churches and other religious associations and did not expect any privileges for itself. At the same time, they pointed to the status of the Holy See as a legal person under public international law and to the need that fact entailed to diversify the forms under which the relations between the state and the Church would be regulated: "It is not the fault of the Catholic Church," Bishop Tadeusz Pieronek said, that "the Orthodox Church and the Protestant Churches do not have a legal personality under international law, as they have chosen to be state churches. Hence, we have no objections as to the equality of Churches before the law. The Catholic Church will be pleased if the Constitution ensures such equality for all"-see "Wolność religijna obywatelom i Kościołowi, 1997, p. 3; and "Potrzeba uszanowania misji Kościoła," 1995, p. 5.

64 For more on this, see primarily Leszczyński, 2012. Also, for an interesting attempt to interpret the religious article in this aspect, see Olszówka, 2010. This matter is also discussed in a multi-authored monograph Układowe formy regulacji stosunków między państwem a związkami wyznaniowymi (art. 25 ust. 4-5 Konstytucji RP) (Stanisz and Ordon, 2013). 
legal solutions that were developed as a result of extremely turbulent constitutional work. ${ }^{65}$

The freedom of conscience and religion, as a personal human right, derives from natural law, especially the inherent and inalienable dignity of the person, which is the source of freedoms and rights, including the freedom of conscience and religion. Pursuant to Article 30 of the Polish Constitution of April 2, 1997, human dignity is "inviolable." The respect and protection thereof shall be the obligation of public authorities. It follows from this provision that the freedom of conscience and religion is an inherent human right that is vested in the person regardless of the decisions of anyone, especially state authorities.

In addition to dignity, the value underlying religious freedom in Poland is the freedom to do whatever a person believes is right, as long as this does not violate the freedom and rights of other persons. ${ }^{66}$ Further, Article 32 of the Constitution contains guarantees of the third value, which is at the same time the fundamental and general rights of all persons to whom Polish law applies and an obligation on the Republic of Poland. ${ }^{67}$ That is, equality is an extremely important value in the process of exercising religious freedom, as confirmed, inter alia, in Article 25(1) of the Constitution, which stipulates that churches and other religious organizations have equal rights. In this way, the Constitution framers expressed a personalistic vision of freedoms and the rights of persons and citizens. ${ }^{68}$

Every person has the right to exercise freedom from conscience and religion. In Article 53(1), the drafters of the Polish Constitution defined those who individually or collectively exercise religious freedom with the word "everyone," thus indicating that nationality and place of residence or stay do not affect the right to the freedom in question. The freedom of conscience and religion may not be grounds for discrimination in political, social, or economic life, as resolved under the fundamental principle of equality, which applies to all freedoms and rights guaranteed in the

65 It should be noted that the freedom of conscience and religion in the jurisprudence of the Constitutional Court before the entry into force of the 1997 Polish Constitution was covered in the Polish report prepared by judge of the Constitutional Court Andrzej Mączyński and the general report prepared by judges of the Constitutional Court Wiesław Johann and Biruta Lewaszkiewicz-Petrykowska for the XI Congress of the Conference of European Constitutional Courts devoted to the issues of freedom of conscience and religion in constitutional jurisprudence; see Johann and Lewaszkiewicz-Petrykowska, 1999, pp. 15-29; Mączyński, 1999, pp. 50-59.

66 CF. Article 31 of the Polish Constitution.

67 Cf. Majchrowski and Winczorek, 1998, p. 60.

68 The extensive Chapter II of the Polish Constitution provides, besides the principle of respect for dignity, freedom and equality, for a codification of natural law in that it distinguishes between personal freedoms and rights (Articles 38-56), political freedoms and rights (Articles 57-63), and economic, social and cultural freedoms and rights (Articles 64-76), means for the defence of freedoms and rights (Articles 77-81) and citizens' obligations (Articles 82-86). Maria Kruk put it as follows: "In this way, the state recognizes the superiority of human rights and freedoms as those that it cannot dispose of, although it is also bound by the democratic order and international norms when defining the rights of citizens" (Kruk, 1997, p. 14). 
Constitution ${ }^{69}$ : "All persons shall be equal before the law. All persons shall have the right to equal treatment by public authorities."70

Parents are the subjects of religious freedom in the second place ${ }^{71}$ : "the status of the family as a subject of religious freedom is usually justified by the need for parents to decide on the extent and direction to which and in which these rights are exercises by their children." 72 Therefore, in Article 53(3), the Constitution guarantees that "parents shall have the right to ensure their children a moral and religious upbringing and teaching in accordance with their convictions." The general wording contained in Article 48(1), to which the second sentence of Article 53(3) refers, poses many difficulties in interpretation and may also contribute to the weakening of parental authority. ${ }^{73}$ It should be noted that as far as the exercise of parents' rights resulting from religious freedom is concerned, guardians who substitute for parents unable to raise their children are equated with them. ${ }^{74}$ Parents may be deprived of the right to raise their children or may be limited in their rights only on the basis of a final court judgment issued under a statute. ${ }^{75}$

Children have the right to upbringing, which should be provided primarily by their parents. ${ }^{76}$ A divergence of opinions arises in the case discussed above, that is, the granting of freedom of conscience and religion to minors. ${ }^{77}$

The subjects of freedom of conscience and religion in teaching religion at school are churches or other religious associations. The status of the subject of this freedom vesting in churches and other religious associations in this respect results directly from the status of parents and children. Article 53(4) of the Constitution provides that "the religion of a church or other legally recognized religious organization may be taught in schools, but other peoples' freedom of religion and conscience may not be infringed thereby." The provisions of the Polish Constitution, in this regard, uphold the provisions of the Education System Act of September 7, 1991, from which it follows that "[p]ublic kindergartens, primary schools, and middle schools organize religious education at the request of parents, public upper secondary schools at the

69 Cf. Article 32(2) of the Polish Constitution.

70 Article 32(1) thereof.

71 Krukowski, 2000b, p. 95.

72 Cf. Pietrzak, 1997, p. 33.

73 "Parents shall have the right to rear their children in accordance with their own convictions. Such upbringing shall respect the degree of maturity of a child as well as their freedom of conscience and belief as well as their convictions."

74 Cf. Krukowski, 2000b, pp. 95-96.

75 Cf. Article 48(2) of the Polish Constitution.

76 Cf. Krukowski, 2000b, pp. 94-96.

77 Cf. Pietrzak, 1997, p. 33. Contemporary constitutional regulations of democratic states of law either transfer that entitlement to parents or guardians, or grant minors aged 10 to 18 the right to exercise the freedom of conscience and religion independently. The Constitution of the Republic of Poland restricts parents' right to religious and moral upbringing of their children internally (e.g., within the family) and externally (e.g., at school) for the benefit of minors. However, it does so in a vague manner, which may be a source of multiple misunderstandings and conflicts, especially in the case of differing views between parents or guardians and children. 
request of parents or students themselves; after reaching the age of majority, students decide whether or not to study religion." Thus, parents or students themselves decide whether to attend religious lessons, and choose their own religious association. This solution indicates that religious education is optional in Poland. The status of the subject of this freedom vesting in churches and other religious associations as entities with legal personality is expressed in their right to establish and run public or private schools and institutions, in accordance with the provisions of Article 5(2)(3) of the Education System Act.

It should be noted that public authorities are also subject to freedom from conscience and religion. At the same time, Krukowski emphasizes that "the state as a political structure by its nature is not a subject capable of performing religious acts, as its powers relate to the order of temporal reality." 78

Moving on to a brief analysis of the objects of the freedom of conscience and religion, one should first note that the "freedom of conscience" was not defined by the Constitution framers, and the doctrine takes the position that it means freedom in the internal dimension, which includes both the freedom of philosophical choice (religious or irreligious, adopted within an existing religious community or individual one), as well as the freedom to make moral choices and judgments. ${ }^{79}$

However, with regard to the freedom of religion, the Constitutional Court rightly noted that "freedom of religion is set out in very general terms in the constitutional norm, as it covers all religions and affiliation to all religious organizations; therefore, it is not limited to participation in religious communities that form a formal, separate organizational structure and registered in the relevant registers kept by the public authority." 80 This conclusion of the Constitutional Court was warranted by the wording of paragraph 2 in Article 53 of the Polish Constitution, from which it follows that freedom of religion not only includes the freedom to profess or accept religion at one's own discretion, but also to manifest it individually or with others, publicly or privately by worshiping, praying, participating in ceremonies, performing rites, and teaching. Moreover, freedom of religion also includes the possession of sanctuaries and other places of worship for the satisfaction of the needs of believers as well as the rights of individuals, wherever they may be, to benefit from religious services of

78 Krukowski, 2000b, p. 98.

79 This, for example, in Krukowski, 2005, p. 73; Banaszak, 2009, p. 271; Stanisz, 2016, p. 165.

80 Judgement of the Constitutional Court of 16 February 1999, case ref. SK 11/98. In this judgement, the Constitutional Court ruled on the incompatibility of para. 132(4) of the Regulation of the Minister of National Defence of 19 December 1996 on the military service of professional soldiers (Journal of Laws of 1997, No. 7, item 38, as amended) with Article 32 of the Constitution of the Republic of Poland of 2 April 1997 and Article 80(2) of the Act of 30 June 1970 on the military service of professional soldiers (consolidated text of 1997, Journal of Laws No. 10, item 55, as amended), and thus with Article 92(1) of the Constitution. At the same time, the Court determined that the challenged provision of the Regulation was compatible with Article 53(1) and (2) of the Polish Constitution. 
religion, which are referred to by the doctrine as special pastoral care..$^{81}$ The Court pointed out that the broad understanding of the concept of the freedom of conscience and religion under Article 53 of the Polish Constitution is adequate to its perception in the light of Article 9 of the European Convention for the Protection of Human Rights and Fundamental Freedoms. It should be noted that the right to manifest religion also includes the right to do so with the use of signs and symbols that express religious affiliation and personal adherence to a specific set of beliefs. The custom of wearing a cross (or a scapular or medal with the image of the Mother of God or saints) is additionally sanctified in Poland (and not only) by an established and quite carefully cultivated tradition. ${ }^{82}$ As is clear from the constitutional provision, the right to manifest religion also covers activities undertaken "collectively," a number of which are related to the display of religious symbols such as the cross.

Among the constitutional guarantees regarding the freedom of conscience and religion, there are also provisions concerning the teaching of religion. Article 53(4) of the Polish Basic Law provides that "the religion of a church or other legally recognized religious organization may be taught in, but other peoples" freedom of religion and conscience schools not be infringed thereby." Interestingly, in this way, religion as the only subject in public education received a constitutional rank, which was also confirmed in the international agreement of the Concordat between the Holy See and the Republic of Poland on July 28, 1993, ratified on February 23, 1993. These are important insofar as the withdrawal of religion from schools, postulated by left-wing and liberal circles, would require amendments to supra-statutory law, which, in the situation of divisions on the political scene and, consequently, difficulties in gaining an appropriate majority, is difficult.

In Poland, at the constitutional level, restrictions were also defined with regard to the manifestation of religion, which results from the fact that the manifestation of religion is not absolute. However, these restrictions must fulfill the conditions expressly set out in Article 53(5) of the Constitution of the Republic of Poland, acts and provisions of international law, particularly Article 9(2) of the Convention for the Protection of Human Rights and Fundamental Freedoms. The Constitution framers decided that the freedom to publicly express religion may be limited only by means of statute and only "where necessary for the defense of state security, public order, health, morals, or the freedoms and rights of others." The catalog of premises indicated in this provision is practically the same as the general regulation concerning all freedoms and rights specified in Article 31(3) of the Constitution. The difference lies in the lack of "protection of the natural environment" among the substantive premises justifying any restrictions on the manifestation of the freedom of religion.

81 Cf. Krukowski, 2006, pp. 167-179. In the constitutional complaint, the applicant argued that para. 132(4) of the Regulation of the Minister of National Defence on the military service of professional soldiers violates the right to choose to manifest and practice religion guaranteed in the Constitution, as it prevents a person whose religious principles are in conflict with military service from leaving the army.

82 Stanisz, 2016, p. 169. 
In view of the general principles of legal construction in Poland, in this case, the principle lex speciali derogat legi generali applies, where Article 53(5) is lex specialis and Article 31(3) is lex generalis. ${ }^{83}$

The rank of the freedom of conscience and religion among constitutional freedoms and rights is also upheld under Article 233 of the Polish Basic Law, ${ }^{84}$ from which it follows that the introduction of further-reaching limitations is not justified by the order of any of the three extraordinary measures (i.e., martial law, state of emergency, or state of a natural disaster).

Unlike the restrictions on the manifestation of religion, as discussed above, the Polish Constitution framers did not create a special catalog of means for defense of the freedom of conscience and religion. This means that, in this case, general constitutional measures apply, as provided for with respect to all freedoms and rights upheld in Chapter II of the Basic Law.

The system of protection of freedoms and rights is defined in Articles. 77-81 of the Constitution of the Republic of Poland on April 2, 1997, is a novel solution in Polish constitutional practice. However, these are not all legal protection measures provided by the Polish Constitution framers, as some guarantees are outside this catalog. The key to safeguarding the freedom of conscience and religion at the constitutional level lies in the principle set out in Article 31(1) and (2): "Freedom of the person shall receive legal protection. Everyone shall respect the freedoms and rights of others. In the event of a violation of the freedom of conscience and religion, the Constitution provides several protection measures: fundamental is the right to a fair trial (Article 45). It follows from the constitutional provision that every person, that is, the person concerned or a specially appointed body, or the prosecutor, has the option to initiate proceedings and the case should be heard before a competent, impartial, and independent court. This is a systemic principle that provides for the positioning of the judiciary in the system of public authorities, and also applies to judges and their standing. In view of the negative historical experience in this respect, inter alia, the openness of hearings was already guaranteed at the constitutional level. There are exceptions to this principle, and it is up to the court to decide to keep the proceedings close to the public. However, the verdict is publicly announced.

As a measure of protection of freedoms and rights, being a complement and determination (lex specialis) of Article 45(1), the Constitutional Court recognized the right to compensation for damages. ${ }^{85}$ It follows from Article 77(1) of the Constitution (which opens the above-mentioned catalog of means for defense of freedoms and rights) that "[e]veryone shall have the right to compensation for any harm

83 For more on this, see Sobczyk, 2019b, pp. 19ff. The Constitutional Court concluded that "Article $31(3)$ is lex generalis in relation to all constitutional freedoms and rights, regardless of whether specific provisions set out separately the conditions for limiting a right or freedom"-Judgement of the Constitutional Court of 10 April 2002, case ref. K 26/00.

84 This is one of the provisions of the Chapter on extraordinary measures.

85 Judgement of the Constitutional Court of 10 May 2000, case ref. K 21/99. 
done to him by any action of an organ of public authority contrary to law." The premises of liability for damages on the part of public authorities are a public authority, an action of a public authority, a harm understood in accordance with the concept under civil law. The ratio legis of such constitutional solutions is based on respect for the principle of a democratic state ruled by law, in particular legalism, and the guarantee function. Liability for damages is not based on the principle of fault, which means that anyone to whom harm has been caused by the unlawful action of a public authority has the right to compensate for the harm regardless of the fault, or a lack of it, on the part of an officer of that authority. ${ }^{86}$ The State Treasure bears the liability for actions of bodies of all types of public authority taken in this capacity, and the extent of compensation should be determined on the basis of the Civil Code, especially Article $361 \S 1 .{ }^{87}$ In the context of this measure (Article 77 (2)), a guarantee is provided that "[s] tatutes shall not bar the recourse by any person to the courts in pursuit of claims alleging infringement of freedoms or rights."

The right to a fair trial is linked to the staged structure of court proceedings, as referred to in Articles 78 and 176 of the Polish Constitution. The ratio legis of this principle is expressed in the optimal and relatively uniform implementation of the norms of substantive law. The constitution framers shaped that principle relatively broadly in terms of its subjects and objects: "Each party shall have the right to appeal against judgments and decisions made at the first stage." The provision cited refers to participants in the proceedings and all kinds of statements by public authorities.

A novum in Polish constitutional law, modeled on German solutions, is an individual constitutional complaint. Under Article 79 of the Basic Law, everyone has the right to seek protection of their freedoms and rights violated by bodies of public authority in accordance with the principles specified by the statute. The subject is, therefore, every person under the jurisdiction of the Republic of Poland. The extent of protection is broad, as it covers Polish citizens, foreign citizens, and stateless persons. This protection has a double meaning: on the one hand, it serves to protect individual interests and, on the other hand, to protect the public interests. A distinctive feature of the Polish individual constitutional complaint is its subsidiary nature, as it concerns a situation in which a court or a public administration body has made a final decision on freedoms or rights (including as a matter of course the freedom of conscience and religion) or on obligations specified in the Constitution. The rules for filing a constitutional complaint are specified in the Act of November

86 This was confirmed in the judgement of the Constitutional Court of 4 December 2001, case ref. SK $18 / 00$.

87 See ibid. 
30,2016 , on the organization and procedure before the Constitutional Court, Journal of Laws of 2016, item 2072.88

The institution of the Commissioner for Citizens' Rights is also a means of defending the freedom of conscience and religion. The right to complain to the commissioner applies where freedoms or rights have been violated by public authorities. Such a complaint amounts to an application for assistance in the protection freedoms or rights violated, but the complaint itself does not warrant protection. Only the commissioner's initiative can bring a case to a desired end. The catalog of powers vested in the Commissioner for Citizens' Rights is defined in the Commissioner for Human Rights Act. ${ }^{89}$

Apart from the catalog of measures for the protection of freedoms and rights, there is-similar to the right to a fair trial-the right to submit petitions, complaints, and proposals. The broadly understood right to petition is rooted in the tradition of democratic constitutionalism. Complaints and proposals have wellestablished meanings under the applicable law, as the procedure for examination of complaints and proposals is defined by the Code of Administrative Procedure Act of June 14, 1960. ${ }^{90}$ The distinctive features of these measures are as follows: they are often combined; they are publicly available forms of legal action; they serve the protection of all individual, group, and public rights and interests; they complement the other constitutional measures of defense; and they cannot be used to initiate court proceedings. ${ }^{91}$ In turn, the petition as such is a novum not only in the Constitution, but also in Polish law. The Petitions Act of July 11, 2014 is an extension of constitutional guarantees in this respect. ${ }^{92}$ It should be noted that in democratic countries, the petition is a means by which an individual or group addresses a public authority with a request for specific action. In view of the fact that the drafters of the Polish Constitution distinguished between petitions, complaints, and proposals, the content of the request determines whether a letter is a petition, and not its external form, as in Article 3 of the Petitions Act cited above. A petition as a defense measure may include a question for a public authority, elements of criticism, proposals for reforms, changes, desired actions, and others. The right to petition entails an obligation to respond.

88 Act of 30 November 2016 on the organization and procedure before the Constitutional Court (Journal of Laws of 2016, item 2072). This act provides, among other things, as follows (Article 77): “1. A constitutional complaint may be brought after the legal route has been exhausted, provided that this route is foreseen, within 3 months of the delivery of a final judgement, final decision or other final resolution to the complainant. 2. A constitutional complaint shall be examined by the Court on the terms and in the manner provided for examining applications on the conformity of normative acts with the Constitution, ratified international agreements or statutes."

89 Commissioner for Human Rights Act of 15 July 1987 (Journal of Laws of 1987, No. 21, item 123).

90 Code of Administrative Procedure Act of 14 June 1960 (Journal of Laws of 1960, No. 30, item 168).

91 The last of these features also applies to petitions, as confirmed by the Constitutional Court in its judgement of 16 November 2004, case ref. P 19/03.

92 Journal of Laws of 2014, item 1195. 


\section{Guarantees according to other sources of universally binding law}

Moving on to the indication of other sources of Polish law related to the presence of religious symbols in public spaces, it should be noted at the outset that "the sources of religious law are norms enacted or recognized by the state, with the help of which it determines the legal standing of a person due to their religion and the legal standing of churches and other religious organizations." The systematics of the sources of religious law, as a section in the legal system, results from the hierarchy of sources of law adopted by the Polish Constitution framers in Chapter III of the 1997 Constitution. The framers of the Polish Constitution distinguished between universally binding sources of law and acts of internal law. Article 87(1) states that the sources of universally binding law in Poland are the Constitution, statutes, ratified international agreements, and regulations. Under Article 87(2), the sources of universally binding Polish law are enactments of local law issued by the operation of organs in the territory of the organ issuing such enactments. Acts of internal law, under Article 93 of the Constitution, are also the source of law..$^{93}$

The Concordat between the Holy See and the Republic of Poland, signed in Warsaw on July 28, 1993 and ratified on February 23, 1998, occupies a special place among the sources of religious law relating to the relations between the state and the Catholic Church. ${ }^{94}$ Due to the mode of ratification under an act in which the Sejm agreed to the ratification of the Concordat by the President of the Republic of Poland, in the event of a conflict between concordat norms and statutory norms, the former prevails. ${ }^{95}$ There are no provisions in the Concordat that would directly refer to religious symbols in public spaces in genere, nor to the cross in species. The conduct of religious services by the Catholic Church is governed by Article 8, which reads:

1. The Republic of Poland guarantees the Catholic Church the freedom to conduct religious services in accordance with Article 5. 2. The organization of public worship shall fall within the competence of Church authorities, in accordance with Canon Law and with regard to the relevant Polish laws. 3. The State shall guarantee the inviolability of places designated by the competent Church authorities

93 Sobczyk, 2014, pp. 591-603.

94 Journal of Laws of 1998, No. 51, item 318.

95 The procedure for ratifying and terminating international agreements of particular importance for the state is called in the doctrine of international and constitutional law a "major ratification," and relies on a consent of the legislature, by virtue of a statute, to the ratification of the agreement by the President of the Republic of Poland. Article 89(1) of the Polish Constitution provides that 'Ratification of an international agreement by the Republic of Poland (...) shall require prior consent granted by statute' in specific cases set out in the Constitution. 
for the purposes of religious services and for the burial of the dead. For important reasons and with the consent of the competent Church authorities, such places may be used for other purposes. This provision shall not restrict the application of Polish law in cases of expropriation in accordance with the provisions of international law. 4. The performance of public worship in places other than those specified in para. 3 shall not require permission from state authorities unless otherwise determined by the relevant provisions of Polish law, in particular with regard to security and public order. 5. Public authorities may take required measures in the places referred to in para. 3, even without advance notification to the Church authorities, where these are necessary for the protection of life, health, or property.

Among the sources of law relating to the subject matter discussed in this paper, the Act of May 17, 1989 guarantees freedom of conscience and religion. As indicated by the Constitutional Court in its judgment of December 2, 2009, this act "specifies what the freedom of conscience and religion means for citizens, and what it means for Churches and religious organizations, by listing specific rights of citizens and specific rights of Churches and religious organizations, falling within the freedom of conscience and religion, which, on the basis of this act, becomes a comprehensive systemic principle, going beyond the status of the individual's fundamental freedom. A note must also be made that both the rights of the individual (citizens) and the rights of Churches and religious organizations do not constitute a closed-ended catalog, which is consistent with the understanding of the presumption of 'freedom' in a democratic society." 96

The above-mentioned act preceded the adoption of the Polish Constitution and-de jure and de facto-together with two other acts passed on May 17, 1989, started the process of changes in the broadly understood area of religious relations in the state. However, the act does not contain (nor does the Constitution), a direct reference to the presence of religious symbols in public spaces. Of key importance in this matter is the open-ended catalog of specific rights granted to citizens who exercise their freedom of conscience and religion. Active rights include the right to establish religious communities created in order to profess and spread religious faith; have their own system, doctrine, and worship rites; participate in religious services; fulfill religious duties; celebrate religious holy days; belong to churches and other religious associations; profess their religion; to raise children in accordance with one's religious beliefs; maintain contact with fellow believers, including participation in the work of religious organizations on an international scale; use sources of information on religion; make, acquire, and use items necessary for the purposes of worship and religious practices; make, acquire, and possess items necessary to observe religious rules; choose clerical or monastic life; and associate in 
secular organizations in order to carry out tasks resulting from religion or convictions in matters of religion. ${ }^{97}$

According to the position of the Supreme Administrative Court, the Act on guaranteeing freedom of conscience and religion should be construed from the point of view of the relationship between the objective scope of this act and the scope of acts on the relations between the state and individual religious associations, while taking into account the basic principles of Article 25 and Article 53 of the Constitution, as well as from international law in the form of Article 9(1) of the Convention for the Protection of Human Rights and Fundamental Freedoms and Article 18 of the Universal Declaration of Human Rights of $1948 .^{98}$

Apart from the above-mentioned Act on guarantees of freedom of conscience and religion, essential for the religious relations in the state are "specific laws" that regulate the legal standing of individual churches and other religious associations. The model for regulations of this type was the Act of May 17, 1989, on the relations between the State and the Catholic Church in the Republic of Poland. ${ }^{99}$

97 See Article 2 of the Act of 17 May 1989 on the guarantees of freedom of conscience and religion. It should be noted that, in addition to the above catalogue of rights, citizens may also apply for a substitute service due to their religious beliefs on the terms and in the manner specified in the Substitute Service Act of 28 November 2003; and freely work for the benefit of churches and other religious associations and charity and care institutions, or-at their own request (or in the case of minors, at the request of their parents or legal guardians) - obtain an exemption from work or education for the time necessary to celebrate holy days, in accordance with the requirements of their religion.

98 Cf. also the verdict of the Supreme Administrative Court of 14 October 2014, case ref. II OSK 200/13.

99 These are as follows: Regulation of the President of the Republic of Poland on the relations between the State and the Eastern Old Believers' Church having no clerical hierarchy (Journal of Laws of 1928, No. 38, item 363 as amended); Act on the relations between the State and the Karaim Religious Union in the Republic of Poland (Journal of Laws of 1936, No. 30, item 241, as amended); Act of 17 May 1989 on the relations between the State and the Catholic Church in the Republic of Poland (Journal of Laws of 1989, No. 29, item 154 as amended); Act of 14 June 1991 on financing the Catholic University of Lublin from the state budget (Journal of Laws of 1991, No. 61, item 259 as amended); Act of 4 July 1991 on the relations between the State and the Polish Autocephalous Orthodox Church (Journal of Laws of 1991, No. 66, item 287, as amended); Act of 13 May 1994 on the relations between the State and the Evangelical Church of the Augsburg Confession in the Republic of Poland (Journal of Laws of 1994, No. 73, item 323, as amended); Act of 13 May 1994 on the relations between the State and the Evangelical Reformed Church in the Republic of Poland (Journal of Laws of 1994, No. 73, item 324, as amended); Act of 30 June 1995 on the relations between the State and the Polish-Catholic Church in the Republic of Poland (Journal of Laws of 1995, No. 97, item 482, as amended); Act of 30 June 1995 on the relations between the State and the Seventh-day Adventist Church in the Republic of Poland (Journal of Laws of 1995, No. 97, item 481, as amended); Act of 30 June 1995 on the relations between the State and the Baptist Christian Church in the Republic of Poland (Journal of Laws of 1995, No. 97, item 480, as amended); Act of 30 June 1995 on the relations between the State and the Evangelical Methodist Church in the Republic of Poland (Journal of Laws of 1995, No. 97, item 479, as amended); Act of 20 February 1997 on the relations between the State and the Old Catholic Mariavite Church in the Republic of Poland (Journal of Laws of 1997, No. 41, item 253, as amended); Act of 20 February 1997 on the relations between the State and the Pentecostal Church in the Republic of Poland (Journal of Laws of 1997, No. 41, item 254, as amended); Act of 20 February 1997 on the relations between the State and the Catholic Mariavite 
Regulations, which are instruments that implement statutes, are particularly important for this discussion. The Regulation of the Minister of National Education on April 14, 1992, on the conditions and manner of organizing religious education in public schools, in its $\S 12$ allows for the placement of the cross and reciting of prayers before and after classes. The legislator also indicated that "Saying prayers at school should be an expression of the shared aspiration of students as well as tactful and gentle benevolence on the part of teachers and educators." The significance of this normative act lies in the fact that it contains a provision of generally applicable law, which covers guarantees directly relating to the display of the cross in a public place. The Constitutional Court in its ruling of April 20, 1993, concluded that $\S 12$ of the Regulation "indicates only the possibility, and not the obligation, of placing the cross and saying prayers." Moreover, the Court clarified that the inclusion of that provision in the Regulation "finds its justification in the context of the Recitals to the Education System Act, as well as in Article 13, which provides for an obligation on schools to enable students, inter alia, to maintain their religious identity. Paragraph 3 of that article imposes an obligation on the Minister of National Education to lay down, by way of a regulation, the conditions and manner for schools to fulfill that obligation." Despite the ruling of the Constitutional Court, the issue of the placement of religious symbols still raises numerous doubts in Poland, relating, inter alia, to the placement of symbols other than the cross.

Similar legal solutions have been included in the ordinance of the Minister of National Education on July 3, 1992, on the conditions for ensuring the right to perform religious practices for children and youth staying in educational and care institutions, as well as in holiday camps. § 4 of the ordinance provides that "crosses and other religious symbols may be placed in the facility, taking into account the feelings of students of individual religions and denominations." 100

\section{Limits of religious expression through religious symbols}

In reference to the introductory notes to this paper, it should be emphasized that religious symbols, especially crosses, were "returned to schools, hospitals, and some offices as a result of grassroots initiatives that enjoyed broad social support during the period of democratic transformations." According to the general rules, the continuance of this state of affairs does not require any justification today; rather, any attempt to change it would require such justification. However, for places and rooms

Church in the Republic of Poland (Journal of Laws of 1997, No. 41, item 252, as amended); Act of 20 February 1997 on the relations between the State and Jewish religious communities in the Republic of Poland (Journal of Laws of 1997, No. 41 item 251, as amended).

100 Monitor Polski of 199, No. 25, item 181. 
that are still being arranged, the choice regarding the presence of the cross should be left to the prudent and mature decision of those who will be their users. At the same time, one should agree with the opinion that no one has the right to appropriate public spaces. ${ }^{101}$

Regardless of legal disputes on the placement of religious symbols in public places, on the basis of the interpretation of the above-indicated articles of the Polish Constitution and "religious statutes," restrictions in this respect may result from the requirements of occupational health and safety. ${ }^{102}$

\section{The system of legal protection}

The protection of the presence of religious symbols in public space in Poland in the practice of common courts has been a fact since the political transformation of 1989. Two cases that were heard before the Provincial Court and the Court of Appeal in Łódź, as well as the Regional Court and the Court of Appeal in Szczecin, can serve to illustrate this.

In the former case, in 1990, a cross was placed in the meeting room of the City Council in Łódź. On November 12, 1997, the claimant requested that the Chairman of the City Council remove the cross, referring to Article 25(2) of the Constitution of the Republic of Poland. The petition was referred to a committee and the claimant was not provided a meaningful response. As a result, the claimant brought an action to the Provincial Court in Łódź against the Community of Łódź for the protection of personal rights.

The Provincial Court in Łódź, in its decision of June 29, 1998, ${ }^{103}$ found that the claim was unfounded given the facts of the case. The claimant derived his claim from the provisions on the protection of personal rights. In the justification of the decision, the Court of the first instance undertook, inter alia, as is important from the point of view of the present considerations, to interpret Article 25(2) of the Polish Constitution, to conclude that the placement of the cross was not unlawful. The impartiality of public authorities in matters of personal religious or philosophical convictions applies to the exercise of the functions of the authority by making and applying legal enactments within its territory. It does not apply to the interior design of the premises of collective bodies. The presence of the cross is neither prohibited by the Constitution of the Republic of Poland, which also refers to God in its Preamble, nor by ordinary statutes. ${ }^{104}$ 
The Court of the first instance also referred to Article 18 of the International Covenant on Civil and Political Rights, Article 9 of the European Convention for the Protection of Human Rights and Fundamental Freedoms, and the judgment of the Supreme Court of September 6, 1990. ${ }^{105}$

The Court of Appeal in Łódź dismissed this appeal after hearing the case brought by Łukasz M. against the Community of Łódź for the protection of personal rights as a result of the claimant's appeal against the decision of the Provincial Court in Łódź of June 29, 1998, case ref. II C 2857/97. ${ }^{106}$

The Court of Appeal in its judgment of October 28, 1998 referred inter alia to the symbolism of the cross, noting that "the symbol of the cross in the experience of the Polish Nation, apart from the religious meaning for essentially all Christian denominations, and not just one, has entered the social consciousness also as a symbol of death, pain, suffering, sacrifice, and reverence to all those who fought and fell for freedom and independence during the national liberation struggle during the partitions and during the wars with invaders." 107

Further, the Court stated that "the symbol of the cross next to the state emblem is an expression of the community's exercise of its own subjective rights in relation to the extraordinary history of their country and the people who gave their lives for it. The exercise of one's subjective rights precludes the unlawfulness of an act." 108 The court pointed to one of the fundamental principles defining the status of an individual in the state-the principle of freedom expressed in Article 31(2) of the 1997 Polish Constitution-as follows: " everyone shall respect the freedoms and rights of others." The Court's opinion stated that when exercising their rights, an individual may not deprive others of the right to cultivate their tradition, culture, customs, and pursue collective feelings, which, in relation to the existence and continuity of the State, are realized in the performance of public functions sensu largo to the extent that goes beyond making and applying the law. ${ }^{109}$

Hence, the Court of Appeal concluded that the mere presence of a religious symbol in the building of a public authority is not sufficient to determine that the freedom of conscience was violated. ${ }^{110}$

The latter case relates to the dismissal of Lesław M.'s appeal for the protection of personal rights by the Court of Appeal in Szczecin on November 25, 2010. In the claimant's view, the presence of the crucifix violated, inter alia, his basic constitutional rights as defined in Article 25(2), because a public authority should be impartial, and its use of religious symbolism violated his right to equal treatment

105 Cf. I PRN 38/90-OSNCP 1991/10-12, item 126.

106 Judgement of the Court of Appeal in Łódź of 28 October 1998, case ref. I ACa 612/98 (OSA 1999/6/26).

107 Ibid.

108 Ibid.

109 Cf. ibid.

110 OSP 1999/10, item 177, OSA 1999/6, item 26, 21. 
by that authority because of a different religious conviction. ${ }^{111}$ In his opinion, the display of the cross in the City Hall, which he does not accept or share, could contribute to his affairs being left unresolved or resolved worse than they should.

Regarding the alleged failure on the part of the respondent to observe the principle of impartiality in matters of religious convictions as expressed in Article 25(2) of the Polish Constitution, the Regional Court, in the justification of its decision of March 26, 2010, stated that "this impartiality in the case of the Polish constitutional order does not mean indifference, but rather-as the case law of the Constitutional Court upholds-the principle of benevolent interest, which is manifested in the statutory regulation of relations with certain religious organizations or churches." ${ }^{112}$ In the justification of its decision, the court cited an analysis of the legal obligations of public authorities carried out by the Constitutional Court in the judgment of December 2, 2009. ${ }^{113}$ The Court pointed out that under Article 25(2), public authorities are obliged to ensure everyone the freedom of convictions and the freedom to express the same in public life, as well as the related freedom to make relevant decisions. ${ }^{114}$

The claimant appealed to the decision of the Regional Court, alleging that the challenged decision violated Article 25(2) of the Constitution of the Republic of Poland in recognizing that placing the symbol of the crucifix in the conference room of the City Council and other premises of the City Hall did not undermine the impartiality of public authorities in matters of religious and philosophical beliefs of the claimant.

In the opinion of the appellant, the unlawfulness of the respondent's action was demonstrated, inter alia, by its acceptance of the display of crucifixes and crosses in public places, which in his opinion supported the argument that the respondent, in exercising public authority, was not impartial in matters of religious and philosophical convictions and actually induced the claimant to recognize the Catholic religion as his own, which violated Article 25(2) of the Constitution of the Republic of Poland and Article 14 of the Convention for the Protection of Human Rights and Fundamental Freedoms.

111 Cf. Judgement of the Court of Appeal of 25 November 2010, case ref. I ACa 363/10.

112 Judgement of the Regional Court of 26 March 2010, case ref. I C 28/10.

113 Judgement of the Constitutional Court of 2 December 2009, case ref. U 10/07.

114 In the same justification for its judgement, the Court stated that "the impartiality of public authorities in the Republic of Poland, referred to in Article 25(2) of the Constitution may not be understood as factual institutional equality between the Roman Catholic Church, which dominates in Polish society in terms of the number of believers, and other churches and religious organizations. The impartiality of public authorities in matters of religious and philosophical convictions does mean, however, that it is admissible that the existing status quo in the sphere of the religious structure may be changed, but this without state interference, in a 'natural' manner, as a result of the evolution of the structure of social consciousness, with the existing freedom of religious or philosophical beliefs, and the freedom of choice made by each individual." 
The Court of Appeal concluded that the claimant's appeal was unfounded. For the most part, it upheld the arguments of the Regional Court regarding the violation of the appellant's personal rights. ${ }^{115}$

To conclude this section, the seven lawsuits filed with the Regional Court in Warsaw by deputies of the Palikot's Movement should be noted. In these lawsuits, the deputies demanded that the Latin cross be removed from the assembly room of the Sejm. The legal construction of the lawsuits referred to the protection of personal rights under Article 24 of the Civil Code. This case has been described in detail in the literature. ${ }^{116}$

\section{Conclusions}

In contemporary democratic states ruled by law characterized by religious pluralism, the place and meaning of religion and religious symbols in culture, law, and tradition are changing. The role of religious symbols as factors that consolidate the state and that are essential for proper operation is diminishing. As a consequence, with the proclamation of the freedom of conscience and religion and the separation of church and state, religious symbols cease to be components of national identity. ${ }^{117}$ Nevertheless, such processes may prove beneficial to religion, as religious symbols will begin to be identified with religion itself again rather than with culture, state, or tradition.

The recent history of the Polish state in particular made religious symbols-especially the cross-important factors integrating the nation and a symbol of the struggle for independence and sovereignty. Placing crosses in public places in Poland was an expression of the fight against invaders and occupiers, and after the country regained sovereignty in 1989, it became an important element in the country's "return to its roots and Christian identity."

The Polish Constitution of 1997 contains a number of guarantees of the rank of constitutional principles and values, which relate to the display of religious symbols

115 It should be noted that the Court of Appeal pointed out that "in Poland, crosses are not only found in or near sacred buildings. They are placed, for example, by roads to commemorate the victims of accidents or to warn others of their consequences; in squares in cities, villages, or even outside the residential areas, at crossroads. Moreover, crosses are present in the Polish Sejm and Senate. Therefore, it cannot not be possibly assumed that the claimant is not aware of it, or-in the case of the assembly rooms of the Sejm and the Senate-does not notice it, if only while watching the reports from the sessions presented in television news programs. The claimant does not claim, however, that the sight of these crosses-especially in the Sejm and Senate-violates his personal rights."

116 In particular, see Sadomski, 2015, pp. 221-240; Zawiślak, 2016, pp. 174-177.

117 Szymanek, 2012, p. 37. 
in public spaces. Article 53 (freedom of conscience and religion) and Article 25(2) (the impartiality of public authorities) are of particular importance in this respect.

Polish constitutional solutions related to the manifestation of religion significantly overlap with the wording of Article 9 of the European Convention for the Protection of Human Rights and Fundamental Freedoms and (at least partially) with the construction made by the European Court of Human Rights in Strasbourg.

The basic constitutional guarantees concerning the freedom to manifest religion were reiterated in the Concordat, the "religious statutes," and other legal acts. None of these prescribe or prohibit the placement of religious symbols in public places. Among the sources of law essential from the perspective of the presence of religious symbols in public spaces, the following are of key importance: Regulation of the Minister of National Education on April 14, 1992, on the conditions and manner of organizing religious education in public schools, which allows for the placement of the cross and reciting prayers before and after classes, and the Ordinance of the Minister of National Education on July 3, 1992, on the conditions for ensuring the right to perform religious practices for children and youth staying in educational and care institutions, as well as in holiday camps, from which it follows that crosses and other religious symbols may be placed in the facility, taking into account the feelings of students of individual religions and denominations. Thus, these two acts make it admissible to place religious symbols in public spaces.

It can therefore be concluded that the thesis of Michał Pietrzak, one of the most distinguished representatives of the Polish religious law doctrine, that "[n]o religious signs or symbols are placed inside and outside public buildings"118 as "[t]he functions of the state are not performed by religious associations, and religious tasks are not performed by state bodies and institutions," reality.

The analysis of sample court cases on various aspects of the presence of religious symbols in public space, especially in the buildings of public offices, leads to the conclusion that jurisprudence regarding the right to manifest religion addresses numerous cases in which this right has been challenged. Claimants have alleged that the display of crosses is incompatible with the constitutional principle of impartiality and was a violation of personal rights under civil law. Despite certain exceptions, it seems that the existing jurisprudence regarding the presence of religious symbols in Poland warrants a statement that "the line of jurisprudence is well-established." 120 As noted by Wiesław Śniecikowski, "court decisions clearly indicate that the cross can be displayed in the Sejm, just like a cross in the premises of a city office, or a cross worn around the neck without any legal obstacles in the case of airline ground service personnel. The mere fact of displaying a religious symbol in a public authority building is not sufficient to conclude that the freedom of conscience has been

118 Pietrzak, 2013, p. 94.

119 Ibid., 94.

120 This, e.g., in Zawiślak, 2016, p. 173. 
violated, nor is it a form of discrimination against a non-believer, and therefore it does not infringe upon his or her personal rights." 121

The findings of the present study indicate that there is currently no need to amend the applicable legislation on the presence of religious symbols in public spaces. In this respect, the legal bases (primarily under constitutional and international law and statutes) correspond to the religious and social needs of the addressees of legal norms. Turbulent discussions, especially in the 1990s (mainly during the work on the Constitution and the ratification of the Concordat), as well as constitutional and judicial practice have resulted in the development of a relatively universally acceptable status quo.

121 Cf. Śniecikowski, 2016, p. 62. 


\section{Bibliography}

BAnAszaK, B. (2009) Konstytucja Rzeczypospolitej Polskiej. Komentarz. Warszawa: C. H. Beck.

BORECKI, P. 'ZASADA RÓWNOUPRAWNIENIA WYZNAŃ W PRAWIE POLSKIM,” STUDIA Z PRAWA WYZNANIOWEGO 2007/10, PP. 115-159.

BORECKI, P. (2008) Geneza modelu stosunków państwo-kościół w Konstytucji RP. Warszawa: Wydawnictwo Sejmowe.

CimoszewiCZ, W. (1995) Statement in Biuletyn KKZN, 1995/16.

CzoharA, A. (1994) Stosunki państwo-Kościół. Belgia, Francja, Hiszpania Włochy. Warszawa: Instytut Studiów Politycznych PAN.

DUDEK, D. (2004) 'Równouprawnienie kościołów i związków wyznaniowych na tle konstytucyjnych zasad prawa wyznaniowego' in Mezglewski A. (ed.) Prawo wyznaniowe w systemie prawa polskiego. Materiały I Ogólnopolskiego Sympozjum Prawa Wyznaniowego (Kazimierz Dolny, 14-16 stycznia 2003). Lublin: Wydawnictwo KUL.

DuDEK, D. (2016) 'Obecność krzyża w przestrzeni publicznej a zasada bezstronności władz publicznych w Rzeczypospolitej Polskiej’ in Stanisz, P., Zawiślak, M., Ordon, M. (eds.) Obecność krzyża w przestrzeni publicznej. Doświadczenia niektórych państw europejskich. Lublin: Wydawnictwo KUL.

DZIAŁOCHA, W. (1995) Statement in Biuletyn KKZN, 1995/17.

GARLICKI, L. (1999) 'Wolność sumienia i wyznania w orzecznictwie konstytucyjnym—status wspólnot religijnych' in 'Wolność sumienia i wyznania w orzecznictwie konstytucyjnym. XI Konferencja Europejskich Sądów Konstytucyjnych; Warszawa, 16-20 maja 1999,” Biuletyn Trybunału Konstytucyjnego, Special issue, pp. 30-47.

GARLICKI, L. (2012) Polskie prawo konstytucyjne. Zarys wykładu. Warszawa: Liber.

Gowin, J. (1999) Kościół w czasach wolności 1989-1999. Kraków: Znak.

JOHANN, W., LEWASZKIEWICZ-PETRYKOWSKA, B. (1999) 'Wolność sumienia i wyznania w orzecznictwie konstytucyjnym—status jednostki' in 'Wolność sumienia i wyznania w orzecznictwie konstytucyjnym. XI Konferencja Europejskich Sądów Konstytucyjnych; Warszawa, 16-20 maja 1999," Biuletyn Trybunału Konstytucyjnego, special issue, pp. 15-29.

KRUKOWSKI, J. (1993) 'Katolickie postulaty konstytucyjne," Rocznik Teologiczny ChAT, 1993/1, pp. 319-330.

KRUK, M. (1993) 'Wstęp. Między Konstytucją a Konstytucją' in Kruk M. (ed.), Mała Konstytucja w procesie przemian ustrojowych w Polsce. Warszawa: Wydawnictwo Sejmowe.

KRUK, M. (1997) Konstytucja Rzeczypospolitej Polskiej z komentarzem. Warszawa: Awa.

KRUKOWSKI, J. (1999) Konkordat Polski. Znaczenie i realizacja. Lublin: Verba.

KRUKOWSKI, J. (2000a) 'Konstytucyjny system relacji między Państwem a Kościołem katolickim oraz innymi kościołami i związkami wyznaniowymi’ in Mojak R. (ed.) Ustrój konstytucyjny Rzeczypospolitej Polskiej. Lublin: Wydawnictwo UMCS, pp. 95-107.

KRUKOwsKI, J. (2000b) Kościół i Państwo. Podstawy relacji prawnych. Lublin: Wydawnictwo KUL.

KRUKOwSKI, J. (2002) 'Polityka wyznaniowa państw postkomunistycznych. Główne linie.” Roczniki Nauk Prawnych, 12(2), pp. 5-19. 
KRUKOWSKI, J. (2004) 'Konstytucyjny model stosunków między państwem a kościołem w III Rzeczypospolitej' in Mezglewski A. (ed.) Prawo wyznaniowe w systemie prawa polskiego. Materiały I Ogólnopolskiego Sympozjum Prawa Wyznaniowego (Kazimierz Dolny, 14-16 stycznia 2003). Lublin: Wydawnictwo KUL, pp. 79-101.

KRUKOWSKI, J. (2005) Polskie prawo wyznaniowe. Warszawa: LexisNexis.

KRUKOWSKI, J. (2006) Polskie prawo wyznaniowe, 2nd edn. Warszawa: LexisNexis.

KulEsZA, W. (1995) Statement in Biuletyn KKZN, no. 14.

LESZCZYŃSKI, P. (2012) Regulacja stosunków między państwem a nierzymskokatolickimi Kościołami i innymi związkami wyznaniowymi określona w art. 25 ust. 5 Konstytucji RP. Gorzów Wielkopolski: Państwowa Wyższa Szkoła Zawodowa w Gorzowie Wielkopolskim.

MAJCHrowski, J. WinczoreK, P. (1998) Ustrój konstytucyjny Rzeczypospolitej Polskiej. Warszawa: Hortpress.

MAŁAJNY, R. M. (2002) 'Regulacja kwestii konfesyjnych w Konstytucji III RP (refleksje krytyczne)' in Tokarczyk R., Motyka K. (eds.) Ze sztandarem prawa przez świat. Księga dedykowana Profesorowi Wieńczysławowi Józefowi Wagnerowi von Igelgrund z okazji 85lecia urodzin. Kraków: Zakamycze.

MĄCZYŃSKI, A. (1999) 'Wolność sumienia i religii w orzecznictwie polskiego Trybunału Konstytucyjnego' in 'Wolność sumienia i wyznania w orzecznictwie konstytucyjnym. XI Konferencja Europejskich Sądów Konstytucyjnych, Warszawa, 16-20 maja 1999," Biuletyn Trybunału Konstytucyjnego, Special issue, pp. 50-59.

MielCZAREK, M. (2013) Realizacja wolności religijnej w zatrudnieniu pracowniczym. Warszawa: Difin.

MOJAK, R. (2007) 'Kościół a sprawy publiczne w demokratycznym państwie. Podstawy doktrynalne oraz zasady prawne współdziałania Kościoła i państwa w sferze życia publicznego' in Mezglewski, A. (ed.) Funkcje publiczne związków wyznaniowych. Materiały III Ogólnopolskiego Sympozjum Prawa Wyznaniowego (Kazimierz Dolny, 16-18 maja 2006). Lublin: Wydawnictwo KUL.

OLSzówKA, M. (2010) Ustawy wyznaniowe. Art. 25 ust. 5 Konstytucji RP—próba interpretacji. Warszawa: Wydawnictwo UW.

OSIATYŃsKi W. (1995) Statement in Biuletyn KKZN, 1995/14.

OżóG, K. (2010) 'Krzyżu, bądź pozdrowiony. Krzyż w przestrzeni publicznej i społecznej w dziejach Polski’ in Bujak, A., Ożóg, K., Sosnowski, L. (eds.) Krzyż polski, vol. 1, Przybytek Pański. Kraków: Biały Kruk.

PietrzaK, M. (2013) Prawo wyznaniowe, 5th edn. Warszawa: LexisNexis.

Pietrzak, M. (1997) 'Stosunki państwo-Kościół w nowej Konstytucji,' Państwo i Prawo, 1997/11-12, p. 176.

'Potrzeba uszanowania misji Kościoła. Rozmowa z Sekretarzem Generalnym Episkopatu Polski, Biskupem Tadeuszem Pieronkiem.” Nowa Europa, 20 March 1995, p. 5.

SADOMSKI, J. (2015) 'Symbol religijny jako źródło naruszenia dóbr osobistych jednostki. Uwagi na marginesie sporów sądowych o obecność krzyża w instytucjach sądowych' in Biłgorajski, A. (ed.) Wolność wypowiedzi versus wolność religijna. Studium z zakresu prawa konstytucyjnego, karnego i cywilnego. Warszawa, C. H. Beck.

Słownik Języka Polskiego [Online]. Available at: https://sjp.pl/symbol (Accessed: 20 May 2021).

SoBCZYK, P. (2005) Kościół a wspólnoty polityczne. Warszawa: Santiago.

SOBCZYK, P. (2013) Zasada konsensualnego określania stosunków między Rzecząpospolitą Polską a Kościołem Katolickim. Warszawa: Aspra-Jr. 
SoвCZYK, P. (2014) 'Źródła prawa wyznaniowego' in Mezglewski A. (ed.) Leksykon prawa wyznaniowego. 100 podstawowych pojęć. Warszawa: C. H. Beck.

SoвCZYK, P. (2019a) 'Modele relacji państwo-Kościół w konstytucjach Rzeczypospolitej XX wieku' in Paruch W. (ed.) Niepodległość-Suwerenność-Podmiotowość. Polskie projekty polityczne 1918-2018. Warszawa: Wydawnictwo Sejmowe.

SoBCZYK, P. (2019b) 'Porządek publiczny i moralność publiczna wartościami współtworzącymi konstytucyjny porządek aksjologiczny’ in G. Blicharz, M. Delijewski (eds.) Klauzule porządku publicznego i moralności publicznej. Warszawa: Wydawnictwo IWS.

STANISZ, P. (2016) 'Obecność krzyża w przestrzeni publicznej w kontekście wolności myśli, sumienia i religii. Perspektywa polska' in Stanisz, P., Zawiślak, M., Ordon M. (eds.) Obecność krzyża w przestrzeni publicznej. Doświadczenia niektórych państw europejskich. Lublin: Wydawnictwo KUL.

STANISZ, P., ORDON M. (eds.) (2013) Układowe formy regulacji stosunków między państwem a związkami wyznaniowymi (art. 25 ust. 4-5 Konstytucji RP). Lublin, Wydawnictwo KUL.

STANosz, B. (2000) Wprowadzenie do logiki formalnej. Podręcznik dla humanistów. 4th Warszawa: PWN.

SZYMANEK, J. (2000) 'Konstytucyjna regulacja stosunków państwo-kościół (ujęcie komparatystyczne)," Państwo i Prawo, 2000/4, pp. 22-39.

Szymanek, J. 'Bezstronność czy neutralność światopoglądowa państwa (Uwagi na tle art. 25 ust. 2 Konstytucji RP,” Państwo i Prawo, 2004/5, pp. 32-33.

SZYMANEK, J. (2012) 'Obecność symboli religijnych w przestrzeni publicznej' in Wieruszewski, R., Wyrzykowski, M., Kondratiewa-Bryzik L. (eds.) Prawne granice wolności sumienia i wyznania. Warszawa: Wolters Kluwer.

SzYMANEK, J. (2006) 'Prawo wyznaniowe w praktyce III RP (zagadnienia wybrane)', Ruch Prawniczy Ekonomiczny i Socjologiczny, 2006/1, pp. 93-109.

Śniecikowski, W. 'Prawo osób wierzących do uzewnętrzniania religii." Przegląd Prawa Publicznego, 2016/4, pp. 45-64.

WinCZOREK, P. (1995a) Statement in Biuletyn KKZN, 1995/10.

WinCzOREK, P. (1995b) Statement in Biuletyn KKZN, 1995/14.

WinczoreK, P. (2000) Komentarz do Konstytucji Rzeczypospolitej Polskiej z dnia 2 kwietnia 1997 r. Warszawa: Liber.

WIŚNIEWSKI, L. (1995) Statement in Biuletyn KKZN, 1995/10.

'Wolność religijna obywatelom i Kościołowi. Z biskupem Tadeuszem Pieronkiem, Sekretarzem Generalnym Episkopatu Polski, rozmawiają Zdzisław Szuba i Tadeusz Żeleźnik." Słowo. Dziennik Katolicki, 1997/43, p. 3.

ZAWIŚLAK, M. (2016) 'O ekspozycji symboli religijnych w budynkach publicznych' in Longchamps de Berier, F., Szczucki K. (eds.) O wolność słowa i religii. Praktyka i teoria. Warszawa: Wydawnictwo Sejmowe, Fundacja 'Utriusque Iuris."

ZIEMBIŃSKI, Z. (1992) Logika praktyczna. 15th Warszawa: PWN. 


\section{Legal sources}

Constitution of the Republic of Poland of 17 March 1921 (Journal of Laws No. 44, item. 267). Regulation of the President of the Republic of Poland on the relations between the State and the Eastern Old Believers' Church having no clerical hierarchy (Journal of Laws of 1928, No. 38, item 363 as amended).

Act on the relations between the State and the Muslim Religious Union in the Republic of Poland. (Journal Of Laws of 1936, No. 30, item 240 as amended).

Act on the relations between the State and the Karaim Religious Union in the Republic of Poland (Journal of Laws of 1936, No. 30, item 241, as amended).

Convention for the Protection of Human Rights and Fundamental Freedoms signed in Rome on 4 November 1950 (Journal of Laws of 1993, No. 61, item 284).

Constitution of the Polish People's Republic of 22 July 1952 (consolidated text: Journal of Laws of 1976, No. 7, item 36).

Code of Administrative Procedure Act of 14 June 1960 (Journal of Laws of 1960, No. 30, item 168).

Act of 30 June 1970 on the military service of professional soldiers (consolidated text of 1997, Journal of Laws No. 10, item 55, as amended).

Commissioner for Human Rights Act of 15 July 1987 (Journal of Laws of 1987, No. 21, item 123).

Act of 17 May 1989 on guarantees of freedom of conscience and religion (consolidated text: Journal of Laws of 2000, No. 26, item 319, as amended).

Act of 17 May 1989 on the relations between the State and the Catholic Church in the Republic of Poland (Journal of Laws No. 29, item 154, as amended).

Act of 14 June 1991 on financing the Catholic University of Lublin from the state budget (Journal of Laws of 1991, No. 61, item 259 as amended).

Act of 4 July 1991 on the relations between the State and the Polish Autocephalous Orthodox Church (Journal of Laws of 1991, No. 66, item 287, as amended).

Constitutional Act of 17 October 1992 mutual relations between the legislative and executive powers and on local government (Journal of Laws No. 84, item 426, as amended).

Act of 13 May 1994 on the relations between the State and the Evangelical Church of the Augsburg Confession in the Republic of Poland (Journal of Laws of 1994, No. 73, item 323 , as amended).

Act of 13 May 1994 on the relations between the State and the Evangelical Reformed Church in the Republic of Poland (Journal of Laws of 1994, No. 73, item 324, as amended).

Act of 30 June 1995 on the relations between the State and the Evangelical Methodist Church in the Republic of Poland (Journal of Laws of 1995, No. 97, item 479, as amended).

Act of 30 June 1995 on the relations between the State and the Baptist Christian Church in the Republic of Poland (Journal of Laws of 1995, No. 97, item 480, as amended).

Act of 30 June 1995 on the relations between the State and the Seventh-Day Adventist Church in the Republic of Poland (Journal of Laws of 1995, No. 97, item 481, as amended)

Act of 30 June 1995 on the relations between the State and the Polish-Catholic Church in the Republic of Poland (Journal of Laws of 1995, No. 97, item 482, as amended).

Regulation of the Minister of National Defence of 19 December 1996 on the military service of professional soldiers (Journal of Laws of 1997, No. 7, item 38, as amended).

Act of 20 February 1997 on the relations between the State and Jewish religious communities in the Republic of Poland (Journal of Laws of 1997, No. 41 item 251, as amended). 
Act of 20 February 1997 on the relations between the State and the Catholic Mariavite Church in the Republic of Poland (Journal of Laws of 1997, No. 41, item 252, as amended).

Act of 20 February 1997 on the relations between the State and the Old Catholic Mariavite Church in the Republic of Poland (Journal of Laws of 1997, No. 41, item 253, as amended).

Act of 20 February 1997 on the relations between the State and the Pentecostal Church in the Republic of Poland (Journal of Laws of 1997, No. 41, item 254, as amended).

Constitution of the Republic of Poland on 2 April 1997 (Journal of Laws, No. 78, item 483, as amended).

Resolution of the Sejm of the Republic of Poland of 3 December 2009 (Monitor Polski of 2009, No. 78, item 962).

Resolution of the Senate of the Republic of Poland of 4 February 2010 (Monitor Polski of 2010, No. 7, item 57).

Petitions Act of 11 July 2014 (Journal of Laws of 2014, item 1195).

Act of 30 November 2016 on the organization and procedure before the Constitutional Court (Journal of Laws of 2016, item 2072).

Concordat between the Holy See and the Republic of Poland (Journal of Laws of 1998, No. 51, item 318).

\section{Case law}

Judgement of the Constitutional Court of 5 May 1998, case ref. K 35/97.

Judgement of the Constitutional Court of 8 June 2011, case ref. K 3/09.

Judgement of the Constitutional Court of 10 April 2002, case ref. K 26/00.

Judgement of the Constitutional Court of 10 April 2002, case ref. K 26/00.

Judgement of the Constitutional Court of 4 December 2001, case ref. SK 18/00.

Judgement of the Constitutional Court of 16 November 2004, case ref. P 19/03.

Judgement of the Constitutional Court of 2 December 2009, case ref. U 10/07.

Judgement of the Supreme Administrative Court of 14 October 2014, case ref. II OSK 200/13. Judgement of the Provincial Court in Łódź of 29 June 1998, case ref. II C 2857/97.

Judgement of the Court of Appeal in Łódź of 28 October 1998, case ref. I ACa 612/98.

Judgement of the Court of Appeal of 25 November 2010, case ref. I ACa 363/10.

Judgement of the Regional Court of 26 March 2010, case ref. I C 28/10.

Justification to the judgement of the Court of Appeal in Szczecin of 25 November 2010, case ref. I ACa 363/10.

Decision of the Provincial Court in Łódź of 29 June 1998, case ref. II C 2857/97. 